\title{
ПРОБЛЕМЫ КАДРОВОГО ОБЕСПЕЧЕНИЯ ФЕРМЕРСКИХ ХОЗЯЙСТВ В ДАГЕСТАНЕ: ПУТИ РЕШЕНИЯ ПРОБЛЕМ
}

\author{
(c) 2018 Джамалудинова Мадина Юнускадиевна \\ кандидат экономических наук, доцент кафедры «Государственное и муниципальное управление» \\ Дагестанский Государственный Университет \\ 36700, Россия, Республика Дагестан, г. Махачкала, улица Батырая, 4A \\ E-mail: madina0880@mail.ru
}

В работе обозначена актуальность темы. Описана сущность фермерского хозяйства. По мнению специалистов, технологическим прогрессом и инновациями в развитых государствах обеспечивается от 50 до 90\% роста ВВП. Это обязательное условие и основной «мотор» развития всех секторов сферы услуг и промышленности. Кадровый потенциал, система управления и технологический уровень можно обозначить центральным фактором модернизации агропромышленного комплекса (АПК). Поэтому одной из стратегических задач государственного масштаба, сегодня выступает кадровое обеспечение сельского хозяйства (в том числе фермерских хозяйств).

Указаны причины нежелания трудоустройства в фермерских хозяйствах. В работе обозначены проблемы кадрового обеспечения фермерских хозяйств. Рассмотрены мероприятия с помощью, которых можно сформировать конкурентоспособный, качественный кадровый персонал фермерских хозяйств. Сделаны выводы.

Ключевые слова: кадровое обеспечение, импортозамещение, продовольственная сфера, сельское хозяйство.

На сегодняшний день более 49 тыс. крупных, средних и малых сельскохозяйственных организаций функционирует в агропромышленном комплексе России (в том числе в Дагестане). Насчитывается более 249 тыс. крестьянских (фермерских) хозяйств (из них 4 тыс. в Дагестане) и 33 тыс. индивидуальных предприятий (из них 2 тыс. в Дагестане). Более 4,54 млн. человек составляет численность работающих в секторе АПК, а это $6,7 \%$ всех российских трудящихся [5, с.48].

Фермерское хозяйство является особым видом предпринимательской деятельности, которым занимается, зачастую, одна семья. Готовую сельскую продукцию выпускает такая коммерческая организация, которую потом реализовывает с целью последующего получения дохода. Название «ферма» может носить предприятие в том случае, когда более $70 \%$ от всех его товаров занимают именно сельскохозяйственные.

На территории России такие компании стали довольно популярными, так как здесь действует особая их поддержка на государственном уровне. Основная цель современности заключается в гарантировании в целом жизнеспособности сельского хозяйства и в частности фермерского хозяйства как одной из его самых весомых составляющих. Фундаментом продовольственной безопасности страны может стать обеспечение

его прибыльности и конкурентоспособности на внешнем и внутреннем рынках [2, с.45].

Дефицит квалифицированных кадров является одной из причин медленного развития фермерских хозяйств, который вызван низким качеством и уровнем жизни в сельской местности. В современных условиях можно говорить о сокращении численности занятых и ухудшении качественного состава специалистов. Так, на сельское население Дагестана приходится 24,7\% всей численности, из них трудоспособными являются 56\%. В сельскохозяйственном производстве непосредственно занято 16\% от общего количества работающих.

Санкции, связанные с событиями в Крыму, а также спад цен на энергоресурсы, отразились на современном состоянии экономики России, а это сказалось в свою очередь и на положении фермерских хозяйств [7].

Основные причины нежелания трудоустройства в фермерских хозяйствах заключаются в:

- низкой оценке перспектив подъема сельского хозяйства и преодоления его «развала», как результат низкой оценке перспектив собственного развития и карьеры, что противоречит потребностям активных и амбициозно настроенных молодых людей;

- низкой оценке деревни, которая может 
быть комфортным местом проживания, в том числе социальной инфраструктуры;

- низкой оценке возможности найти по специальности достойную работу с заработной платой, которая будет не ниже 15 тыс. руб. и обеспеченностью жильем;

- низкой оценке условий удовлетворения социальных потребностей общения и потребностей личностного развития, развития будущих детей;

- низкой оценке реальности получения государственной поддержки как молодого специалиста сельского хозяйства [6].

Значительный дисбаланс между количеством желающих в фермерских хозяйствах работать и кадровыми потребностями фермерских хозяйств можно этим объяснить. В фермерские хозяйства ежегодно идут работать не более $28 \%$ выпускников сельскохозяйственных вузов, из них около $15 \%$ и года не проработав, из этой сферы уходят на менее квалифицированную, но более оплачиваемую работу.

Самыми актуальными проблемами в условиях инновационной экономики кадрового обеспечения фермерских хозяйств являются:

- выпускники вузов не имеют производственной практики;

- наличие расхождений между требованиями работодателей с качеством квалификации рабочих;

- резкое сокращение подготовки профильных специалистов;

- система профессиональной подготовки рабочих отсутствует;

- преподаватели не имеют современных знаний связанных с инновационными материалами и новыми технологиями;

- неактуальными являются образовательные программы и современным технологиям они не соответствуют [8].

Таким образом, проблемы кадрового обеспечения фермерских хозяйств в Дагестане связаны с тем, что экономические условия работы десять - пятнадцать лет назад от нынешних отличались. Внедрение новых сельскохозяйственных технологий, оборудования должны были привести к переаттестации персонала, но это только привело к текучести кадров, как показала практика. На сегодняшний день практически у каждого фермерского хозяйства Дагестана можно говорить о возникновении проблем связанных с нехваткой управленческих и рабочих специа- листов.

Большой разнородностью можно охарактеризовать трудовые ресурсы, которые сегодня используют в сельскохозяйственной отрасли (учитывая профессиональную подготовку, место постоянного проживания, уровень социализации, национальности, законности нахождения на территории России). Проблему отсутствия кадров в условиях кризиса в фермерских хозяйствах Дагестана решают путём найма на работу из бывших стран СССР рабочих мигрантов, которые даже на не высокий заработок согласны и не требовательны в отношении условий труда [3, c.18].

С отсутствием системы повышения квалификации и профессионального обучения в первую очередь также связан кадровый дефицит. Центры подготовки, которые существуют, как правило, ориентированы на выдачу удостоверений после прохождения ряда формальных процедур обучения и сдачи экзамена или зачета, они не преследуют цель получить реальные профессиональные знания и навыки. При этом лишь малая часть трудовых ресурсов проходит через процедуру такого обучения, что необходимо для выполнения требований саморегулируемой организации по квалификационному составу работников фермерских хозяйств [9].

Исходя из сложившейся практики, работники фермерских хозяйств обучение проходят непосредственно на рабочем месте, выполняя свои должностные обязанности. Мастером производственного обучения выступает более опытный коллега. Как результат, говорить о внедрении новых технологий в работу представляется весьма сложным, которые в свою очередь могут способствовать росту производительности труда и снижению себестоимости работ.

Дефицит работников, которые в фермерских хозяйствах готовы трудиться усиливают также различия в уровне оплаты труда в разных регионах за одну и ту же работу. Можно судить о тенденции перехода работников из одного фермерского хозяйства в другое, так как высокая планка желаемой оплаты труда, не соответствует квалификации, которая имеется и приводит к смене места работы.

Важный момент заключается и в том, что мелкие и средние (по численности) фермерские хозяйства не имеют собственных ресурсов и возможностей осуществить разрешение проблемы кадрового дефицита. В их арсенале существует 
только один способ решения этой проблемы переманить рабочих сегодня из другого хозяйства к себе, и по тем же причинам завтра их потерять [1, с.25].

Сформировать конкурентоспособный, качественный кадровый персонал фермерских хозяйств, возможно при реализации следующих направлений:

1) необходимо создать эффективную систему профессиональной ориентации выпускников школ, средних учебных заведений, которая позволит сформировать по сельскохозяйственным группам специальностей готовность населения к обучению, и последующей самореализации и самообразованию в сельском хозяйстве;

2) необходимо сформировать для аграрного сектора опережающую систему подготовки и переподготовки кадров, исходя из прогнозов развития аграрного рынка труда и стратегии развития региона;

3) необходимо создать единое образовательное, научное, производственное пространство для подготовки квалифицированных специалистов аграрного сектора, основными субъектами которого должны стать представители аграрного бизнеса, профессорско-преподавательский состав и студенческое сообщество. Примерами взаимодействия могут быть: формирование требований к уровню и качеству подготовки сельскохозяйственных кадров, участие работодателей в учебном процессе на этапе формирования практических навыков, подбор потенциальных работников в соответствии с имеющимися вакансиями и их трудоустройство;

4) необходимо возродить систему распределения выпускников аграрных образовательных учреждений, поскольку применительно к аграрному сектору традиционная система отбора и найма работников неэффективна;

5) необходимо сформировать информационную инфраструктуру и освоение информационных ресурсов и технологий сельскими жителями, что позволит обеспечить возможность постоянного доступа к необходимой информации, актуализировать имеющиеся профессиональные знания и навыки, изучить российский и мировой опыт, ознакомиться с новыми технологиями и инновационными разработками в сельском хозяйстве;

6) необходимо сформировать кадровое обеспечение с активной инновационной восприимчивостью, отражающей уровень востребованности специалистами аграрного сектора результатов инновационной деятельности;

7) необходимо разработать систему мотивации и обеспечения социальной защиты трудоспособного населения, которая позволит обеспечить высокую мотивированность как к труду в целом, так и к повышению уровня своего профессионализма;

8) необходимо повысить престижность сельскохозяйственного труда за счет обеспечения хороших условий труда, социально-бытовых условий и достойной заработной платы [4, c.24].

Таким образом, чтобы было бы большое количество людей, желающих работать в фермерских хозяйствах Дагестана, необходимо принимать меры по привлечению их в сельскохозяйственную сферу. Надо стремиться делать саму жизнь привлекательной и перспективной в деревне, сделать так, чтобы образование, жилье были бы доступными, а заработная плата стала достойной, на селе осуществить создание инфраструктуры, проведение газификации, водоснабжения, построить социально-культурные объекты. Кадры пойдут работать в село, если будут эти условия обеспечены, и не будут в города уходить.

Необходимо отметить, что определением доминирующей роли кадрового потенциала характеризуется XXI век, так как основная созидательная сила в становлении конкурентоспособной экономики в целом и сельского хозяйства в частности - это его инновационная и профессиональная составляющие.

\section{Библиографический список}

1. Аксенова Е.А. Управление персоналом. Москва. 2012. 423 с.

2. Асалиев А. М. Развитие трудового потенциала: учеб. пособие для вузов.- Москва. 2015. 281 с.

3. Vasilyeva E.A. Analysis of methodologi calap proaches to human capital measurement // Federalism. 2016. Vol. 44, № 1. P. 89-96.

4. Особенности кадрового обеспечения аграрного сектора // Бизнес без проблем - Персонал. 2016 . № 5.

5. Koerselman K. Theris kand return of human capital investments //Labour Economics. 2014. Vol. 30, № 21, P. 154163. 
6. Как формируется кадровое обеспечение аграрного сектора: проблемы и пути решения // [Электронный pecypc].- URL: http://vestnik.volbi.ru/upload/numbers/332/article-332-1415.pdf (дата обращения 01.10.2018)

7. Роль фермерского хозяйства в обеспечении эффективной экономической деятельности аграрного сектора Дагестана// [Электронный ресурс]._-URL: file://C:/Users/PC_COMP/Downloads/ekukrr_2016_10_8.pdf (дата обращения 03.10.2018)

8. Тенденции формирования кадрового обеспечения в сельском хозяйстве России // [Электронный ресурс].URL: http://min.usaca.ru/uploads/article/attachment/ (дата обращения 02.10.2018)

9. Проблемы и перспективы развития крестьянских (фермерских) хозяйств // [Электронный pecypc].- URL: http://agrovuz.ru/prepodavateljam/konferencii/item/5651-problemy-i-perspektivy-razvitiya-krestyanskikhfermerskikh-khozyauistv-rossii (дата обращения 04.10.2018). 